\title{
PERAN PROMOSI DALAM UMKM TAS DAN SEPATU ROTAN DI PALANGKA RAYA
}

\author{
Oleh \\ Peridawaty $^{1)}$, Ina Karuehni ${ }^{2}$, Vivy Kristinae ${ }^{3)}$ \\ 1,2,3 Universitas Palangka Raya \\ 1 perida60@gmail.com , ${ }^{2}$ karuehni@gmail.com \& ${ }^{3}$ vivykristinae84@gmail.com
}

\begin{abstract}
Abstrak
Pemasaran merupakan bidang utama dalam penelitian ini yang di dalam kegiatan pemasaran, salah satunya adalah strategi desain pemasaran dengan promosi dan keputusan pembelian untuk memperluas pasar. Tujuan penelitian, untuk meningkatkan pendapatan dan memperluas pasar UMKM tas dan sepatu rotan di Palangka Raya, melalui atribut promosi dan perannya untuk keputusan pembelian konsumen. Penelitian ini, menggunakan metode penelitian analisis kualitatif dengan kuesioner penilaian langsung dari 100 sampel UMKM tas dan sepatu rotan di palangka raya. Berdasarkan hasil penelitian di dapatkan bahwa promosi signifikan berpengaruh positif terhadap keputusan pembelian konsumen dengan indicator jangkauan promosi, kuantitas iklan dan kualitas iklan dalam memenuhi kebutuhan dan keinginan konsumen dalam keputusan pembelian bahkan terhadap pembelian berulang. Implikasi penelitian, di harapkan dapat menjadi acuan UMKM untuk meningkatkan promosi dalam kegiatan pemasaran produk sehingga dapat meningkatkan pendapatan dan memperluas pasar.
\end{abstract}

\section{Kata Kunci : Strategi Pemasaran, Promosi, Keputusan Pembelian \&Umkm}

\section{PENDAHUALUAN}

Perkembangan dunia saat ini berjalan dengan pesat, yang menciptakan suatu persaingan yang semakin ketat. Hal ini yang menuntut pelaku usaha untuk lebih peka, kritis dan reaktif terhadap perubahan yang ada, baik politik, sosial budaya, dan ekonomi(Avlonitis \& Panagopoulos, 2010). Persaingan di dunia perdagangan sekarang terbilang sangat ketat. Apalagi dengan adanya globalisasi dan teknologi yang menyebabkan munculnya perdagangan bebas yang membuat dunia seolah tanpa batas(Ahmed, Kristal, \& Pagell, 2014).

Banyak perusahaan kecil di barang dan jasa dari suatu negara yang bersaing dengan negara lain untuk menarik minat konsumen di dalam perdagangan internasional. Di negara berkembang seperti di Indonesia, UMKM (Usaha Masyarakat Kecil Menengah) untuk menarik minat konsumen membeli produk yang ditawarkan maka dibutuhkan adanya promosi yang efektif, harga yang kompetitif dibandingkan harga yang ditawarkan pesaing, kualitas produk yang bermutu dan juga layanan purna jual yang mampu memberikan kepuasan kepada pelanggan(Sulistyo \& Siyamtinah, 2016).

http://ejurnal.binawakya.or.id/index.php/MBI
UMKM harus bekerja keras membuat kebijakan - kebijakan strategis baru dalam kegiatan pemasaran dalam menjual produk dan jasa mereka dalam kaitannya menghadapi persaingan yang ketat dengan competitor yang dapat memberikan value yang lebih besar kepada customer (Abdul-Mohsin, Abdul-Halim, \& Ahmad, 2012). Pada dasarnya dengan semakin banyaknya pesaing maka semakin banyak pula pilihan bagi pelanggan untuk dapat memilih produk yang sesuai dengan apa yang menjadi harapannya. Dalam perkembangan selanjutnya, maka konsumen menjadi faktor kunci penentu atas keberhasilan atau kegagalan suatu unit usaha di dalam memasarkan produknya melalui promosi (Buil, de Chernatony, \& Martínez, 2013).

Pelaku usaha UMKM, harus mampu mengenali secara dini apa yang menjadi kebutuhan dan harapan konsumen saat ini maupun masa yang akan datang. Sehingga, tujuan dari penelitian ini adalah bagaimanakah kegiatan pemasaran dengan peran promosi yang mempunyai kemampuan dalam menarik konsumen agar dapat melakukan pembelian (keputusan pembelian) (Hsu, 2011). Berdasarkan

Vol.14 No.2 September 2019 
teori penelitian, dynamic capability bahwa kemampuan dapat memberikan pengetahuan dasar yang baik mengenai perilaku konsumen yang berarti bagi perencanaan strategi unsurunsur pemasaran yang terpadu (4P, yaitu product, price, promotion, place) yang selalu berkembang sejalan dengan gerak pelaku usaha dan perubahan-perubahan lingkungan pemasaran serta perubahan perilaku konsumen (Teece, Pisano, \& Shuen, 1997).

Perilaku konsumen dalam UMKM, mempunyai implikasi sangat luas terhadap perumusan strategi pemasaran (Adeniran \& Johnston, 2012). Hal ini disebabkan karena strategi pemasaran menyangkut dua kegiatan pokok yang diantaranya adalah pemilihan pasarpasar yang akan dijadikan sasaran pemasaran, serta merumuskan dan menyusun suatu kombinasi yang tepat agar kebutuhan konsumen dapat di penuhi. Sehingga, rumusan masalah penelitian :

1. Bagaimanakah peran promosi dalam meningkatkan keputusan pembelian ?..

2. Bagaimanakah peran promosi dalam memperluas pasar UMKM ?

\section{LANDASAN TEORI Promosi}

Promosi merupakan faktor penting dalam mewujudkan tujuan penjualan suatu perusahaan. Agar konsumen bersedia menjadi langganan, mereka terlebih dahulu harus dapat mencoba atau meneliti barang-barang yang diproduksi oleh perusahaan, akan tetapi mereka tidak akan melakukan hal tersebut jika kurang yakin terhadap barang itu. Disinilah perlunya mengadakan promosi yang terarah, karena diharapkan dapat memberikan pengaruh positif terhadap meningkatnya penjualan (Kotler \& Armstrong, 2011).

Promosi pada unit usaha dapat mengkomunikasikan produk kepada konsumen. Keunggulan-keunggulan dari produk dapat diketahui oleh konsumen dan bisa membuat konsumen tertarik untuk mencoba dan kemudian akan mengambil keputusan untuk membeli suatu produk tersebut. Promosi merupakan salah satu aspek yang penting dalam manajemen pemasaran karena dengan promosi bisa membuat konsumen yang semula tidak tertarik terhadap suatu produk bisa berubah fikiran dan menjadi tertarik pada produk tersebut.

Promosi penjualan merupakan suatu bujukan langsung yang menawarkan insentif atau nilai lebih untuk suatu produk kepada konsumen. Promosi penjualan mencakup suatu variasi yang luas dari alat - alat promosi yang didesain untuk merangsang respon pasar yang lebih cepat atau lebih kuat (Chan, Cheng, \& Hsien, 2011).

Menurut (E. Schultz \& P. Block, 2014), promosi penjualan adalah kegiatan komunikasi pemasaran, selain dari pada periklanan, penjualan pribadi, dan hubungan masyarakat, dimana insentif jangka pendek memotivasi konsumen dan anggota saluran distribusi untuk membeli barang atau jasa dengan segera, baik dengan harga yang rendah atau dengan menaikan nilai tambah. Maka dapat disimpukan bahwa promosi penjualan merupakan salah satu bentuk komunikasi pemasaran yang menawarkan nilai lebih untuk suatu produk.

Beberapa teknik promosi penjualan menurut (Epstein, Flores, Goodstein, \& Milberg, 2016):

\section{Kupon}

2. Price-off deals

3. Premium and advertising specialities

4. Contest and sweepstakes

5. Sampling and trial offers

6. Brand placement

7. Rebates

8. Frequency programs

9. Event sponsorship

Menurut (Weitz \& Bradford, 1999) terdapat lima tahap pada proses keputusan pembelian, seperti yang terlihat di Gambar 2.1 dibawah ini :

\begin{tabular}{|c|c|c|c|c|c|c|c|c|}
\hline $\begin{array}{c}\text { Pengenalan } \\
\text { Masala }\end{array}$ & $\Rightarrow$ & $\begin{array}{l}\text { Pencarian } \\
\text { Informasi }\end{array}$ & $\Rightarrow$ & $\begin{array}{l}\text { Evaluasi } \\
\text { Alternatif }\end{array}$ & $\Rightarrow$ & $\begin{array}{l}\text { Keputusan } \\
\text { Pembelian }\end{array}$ & $\Rightarrow$ & $\begin{array}{l}\text { Perilaku pasca } \\
\text { Pembelian }\end{array}$ \\
\hline
\end{tabular}

Sumber:Weitz \& Bradford,1999:Kotler \& Amstrong,2011(Arch, 2003)

\section{Pengenalan Masalah}

Proses pembelian dimulai ketika pembeli menyadari suatu masalah atau kebutuhan yang dipicu oleh rangsangan internal dan eksternal. Dengan rangsangan internal, salah satu dari

http://ejurnal.binawakya.or.id/index.php/MBI 
kebutuhan normal seseorang, rasa lapar, haus : naik ketingkat maksimum dan menjadi dorongan atau kebutuhan bisa timbul akibat rangsangan eksternal.

\section{Pencari Informasi}

Ternyata konsumen sering mencari jumlah yang terbatas. Serve memperlihatkan bahwa untuk barang tahan lama, setengah dari semua konsumen hanya melihat satu varian, dan hanya $30 \%$

yang melihat lebih dari satu merek dalam varian lain. Sumber informasi utama dimana konsumen dibagi menjadi empat kelompok :

a. Komersial iklan, situs web, wiraniaga, penyalur kemasa,tampilan

b. Publik media massa, organisasi peningkatan konsumen

c. Eksperimental penanganan, pemeriksaan, penggunaan produk

\section{Evaluasi Alternatif}

Beberapa konsep dasar yang akan membantu kita memahami proses evaluasi :

a. Konsumen berusaha memuaskan sebuah konsumen

b. Konsumen mencari manfaat tertentu dari solusi produk

c. Konsumen melihat masingmasing produk sebagai sekelompok atribut dengan berbagai kemampuan untuk menghantarkan manfaat yang diperlukan untuk memuaskan kebutuhan ini.

4. Keputusan Pembelian

Dalam tahap evaluasi, konsumen membentuk preferensi antar merek dalam kumpulan pemilihan. Konsumen mungkin juga membentuk maksud untuk membeli merek yang paling disukai. Dalam melaksanakan maksud pembelian, konsumen dapat membentuk lima sub keputusan: merek, penyalur, kuantitas, waktu, dan metode pembayaran.

\section{Perilaku Pascapembelian}

Setelah pembelian, konsumen mungkin mengalami konflik dikarenakan melihat fitur mengkuatirkan tertentu atau mendengar hal-hal http://ejurnal.binawakya.or.id/index.php/MBI menyenangkan tentang merek lain dan waspada terhadap informasi yang mendukung keputusannya. Komunikasi pemasaran seharusnya memasok keyakinan dan evaluasi yang memperkuat pilihan konsumen dan membantunya merasa nyaman tentang merek tersebut. Karena itu tugas pemasar tidak berakhir dengan pembelian. Pemasar harus mengamati kepuasan pasca pembelian, tindakan pascapembelian, dan penggunaan produk pasca pembelian.

\section{Keputusan pembelian}

Keputusan Pembelian adalah kegiatan konsumen terhadap suatu produk pada dasarnya erat kaitannya dengan perilaku konsumen. Perilaku konsumen merupakan unsur penting dalam kegiatan pemasaran suatu produk yang perlu diketahui oleh unit usaha, karena pelaku usaha pada dasarnya tidak mengetahui mengenai apa yang ada dalam pikiran seorang konsumen pada waktu sebelum, sedang, dan setelah melakukan pembelian produk tersebut (Bauer \& Auer-Srnka, 2012).

Keputusan pembelian merupakan suatu proses pengambilan keputusan akan pembelian yang mencakup penentuan apa yang akan dibeli atau tidak melakukan pembelian dan keputusan itu diperoleh dari kegiatan-kegiatan sebelumnya (Kåre \& Kjell, 2010). Keputusan pembelian adalah sebuah pendekatan penyelesaian masalah pada kegiatan manusia untuk membeli suatu barang atau jasa dalam memenuhi keinginan dan kebutuhannya yang terdiri dari pengenalan kebutuhan dan keinginan, pencarian informasi, evaluasi terhadap alternatif pembelian, keputusan pembelian, dan tingkah laku setelah pembelian (Kåre \& Kjell, 2010). Sedangkan menurut (Kotler \& Armstrong, 2011), yang dimaksud dengan keputusan pembelian adalah suatu proses penyelesaian masalah yang terdiri dari menganalisa atau pengenalan kebutuhan dan keinginan, pencarian informasi, penilaian sumber-sumber seleksi terhadap alternatif pembelian, keputusan pembelian, dan perilaku setelah pembelian.

Lebih luas, pengertian keputusan pembelian merupakan perilaku pembelian Vol.14 No.2 September 2019 
seseorang dalam menentukan suatu pilihan produk untuk mencapai kepuasan sesuai kebutuhan dan keinginan konsumen yang meliputi pengenalan masalah, pencarian informasi, evaluasi terhadap alternatif pembelian, keputusan pembelian, dan perilaku setelah pembelian. Pengertian pemasaran menurut Zineldin and Philipson (2007), adalah: "Suatu proses sosial dan manajerial dimana individu dan kelompok mendapatkan kebutuhan dan keinginan mereka dengan menciptakan, menawarkan dan bertukar sesuatu yang bernilai satu sama lain". Sedangkan menurut Moharam and Shawky (2012): "Pemasaran adalah sistem keseluruhan dari kegiatan usaha yang ditujukan untuk merencanakan, menentukan harga, mempromosikan dan mendistribusikan barang, jasa, ide kepada pasar sasaran agar dapat mencapai tujuan organisasi".

Menurut Morris, Schindehutte, and LaForge (2002), ada lima tahap dalam proses keputusan pembelian, yang terlihat pada Gambar 2.2 berikut:

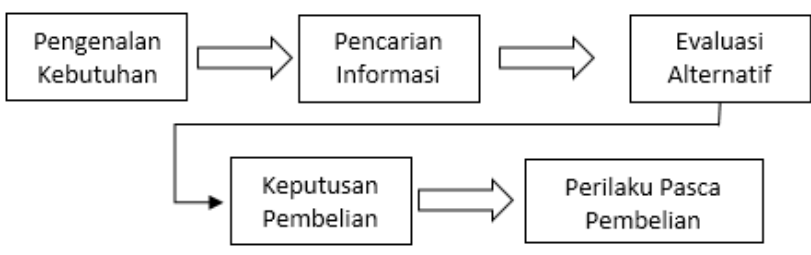

Gambar 2. Proses Keputusan Pembelian Konsumen

Dari Gambar 2.2 tahap-tahap proses keputusan pembelian konsumen dapat dijelaskan sebagai berikut:

\section{Pengenalan kebutuhan}

Proses pembelian dimulai dengan pengenalan kebutuhan. Jika kebutuhan diketahui maka konsumen akan serta memahami kebutuhan yang belum perlu segera dipenuhi atau kebutuhan dapat ditunda pemenuhannya, serta kebutuhan yang sama-sama harus segera dipenuhi. Jadi pada tahap inilah proses pembelian itu mulai dilakukan.

\section{Pencarian Informasi}

Seorang konsumen yang telah mengetahui kebutuhannya dapat atau tidak dapat mencari informasi lebih lanjut jika dorongan

Vol.14 No.1 Agustus 2019 keinginan kuat, jika tidak kuat maka kebutuhan konsumen itu hanya akan menjadi ingatan belaka. Konsumen mungkin melakukan pencarian lebih banyak atau segera aktif mencari informasi yang mendasari kebutuhan.

\section{Evaluasi Alternatif}

Setelah melakukan pencarian informasi sebanyak mungkin, konsumen menggunakan informasi untuk mengevaluasi beberapa merek alternatif dalam satu susunan pilihan.

4. Keputusan Pembelian

Jika keputusan yang diambil adalah membeli, maka pembeli akan menjumpai serangkaian keputusan yang menyangkut jenis pembelian, waktu pembelian, dan cara pembelian. Pada tahap ini konsumen benar-benar membeli produk.

5. Perilaku Setelah Membeli

Setelah membeli suatu produk, konsumen akan mengalami beberapa tingkatan kepuasan atau ketidakpuasan yang dirasakan, ada kemungkinan bahwa pembeli memiliki ketidakpuasan setelah melakukan pembelian karena tidak sesuai dengan keinginan atau gambaran sebelumnya, dan lain sebagainya.

Keputusan pembelian merupakan kegiatan individu yang secara langsung terlibat dalam pengambilan keputusan untuk melakukan pembelian terhadap produk yang ditawarkan oleh penjual (Kotler \& Armstrong, 2011).

\section{METODE PENELITIAN}

Penelitian ini dilakukan di Kota Palangka Raya dan pada 100 UMKM Tas dan Sepatu Rotan di Palangka Raya. Jenis dan sumber data yang digunakan dalam penelitian dengan metode wawancara, observasi dan daftar pertanyaan (kuesioner), guna menjawab pertanyaan dari identifikasi masalah adalah, dengan menggunakan jenis data dibawah ini :

1. Data Primer, merupakan data yang digunakan yang didapat langsung dengan hasil pengisian kuisioner yang diberikan kepada responden, yaitu informasi persepsi responden tentang periklanan, promosi penjualan dan keputusan pembelian.

http://ejurnal.binawakya.or.id/index.php/MBI 
2. Data Sekunder, merupakan data yang didapat dari literature, buku-buku, dan informasi dokumentasi lain yang dapat diambil secara tidak langsung, di antaranya tentang informasi produk yang diteliti (Alan, William, \& Pratim, 2011).

Analisis data kualitatif menurut Bauer and Auer-Srnka (2012) adalah bentuk analisa yang berdasarkan dari data yang dinyatakan dalam bentuk uraian. Data kualitatif ini merupakan data yang hanya dapat diukur secara langsung (Hadi, 2001). Bagian analisis ini akan membahas mengenai bentuk sebaran jawaban responden terhadap seluruh konsep yang diukur.

Dari sebaran jawaban responden selanjutnya akan diperoleh satu kecenderungan atas jawaban responden tersebut. Untuk mendapatkan kecenderungan jawaban responden terhadap jawaban masing-masing variabel akan didasarkan pada nilai rata-rata skor jawaban yang selanjutnya akan dikategorikan pada rentang skor berikut : Skor minimum $=1$ dan Skor maksimum $=5$, Lebar skala $=5-1 / 5=0,8$

Dengan demikian kategori skala dapat ditentukan sebagai berikut :

$1,0-1,80=$ Sangat rendah

$1,81-2,60=$ Rendah

$2,61-3,40=$ Sedang

$3,41-4,20=$ Tinggi

$4,21-5,00=$ Sangat tinggi

Penelitian kualitatif dalam penelitian ini disusun dengan daftar pertanyaan mengenai peran promosi terhadap UMKM tas dan sepatu rotan di Palangka Raya dengan indikatorindikator promosi antara lain :

1. Jangkauan promosi

2. Kuantitas penayangan iklan di media promosi

3. Kualitas penyampaian pesan dalam penayangan iklan di media promosi.

Untuk variabel dependentnya dalam menyusun daftar pertanyaan, indikator-indikator keputusan pembelian :

1. Kebutuhan dan keinginan akan suatu produk

2. Keinginan mencoba

http://ejurnal.binawakya.or.id/index.php/MBI
3. Kemantapan akan kualitas suatu produk

4. Keputusan pembelian ulang

Berdasarkan jawaban-jawaban responden tersebut akan diukur dengan menggunakan skala Likert. Dengan skala Likert, maka variabel yang akan diukur dijabarkan menjadi indikator variabel. Kemudian indikator tersebut dijadikan sebagai titik tolak untuk menyusun item-item instrumen yang dapat berupa pertanyaan atau pernyataan dengan diberi skor/jawaban langsung.

\section{HASIL DAN PEMBAHASAN}

Berdasarkan hasil penelitian yang dilakukan peneliti pada UMKM Tas dan Sepatu Rotan di Palangka Raya, mengenai peran promosi terhadap keputusan pembelian memiliki kesimpulan sebagai berikut :

1. Periklanan yang dimiliki oleh pelaku usaha saat ini berpengaruh positif terhadap keputusan pembelian. Hal ini di lihat dari kuesioner peran promosi dalam keputusan pembelian, sampel 100 UMKM, pada indikator Jangkauan promosi (58 responden menyatakan ini sangat penting poin 5 , dalam menilai keputusan pembelian), indikator kuantitas penayangan iklan di media promosi (70 responden sangat setuju point 5, ini diperlukan),indikator kualitas penyampaian pesan dalam penayangan iklan di media promosi (72 responden menilai setuju point 4 , ini untuk di tindak lanjuti sebagai kualitas dalam keputusan konsumen).

2. Promosi UMKM saat ini dengan melalui diskon dan kontes / event saat ini berpengaruh positif dan signifikan terhadap keputusan pembelian. Hal ini harus dipertahankan dan ditingkatkan. Tetapi, berdasarkan hasil wawancara secara keseluruhan 95\% menyatakan bahwa, saat ini konsumen lebih terdorong untuk melakukan pembelian melalui diskon dan lebih banyak pendapatan di eventevent atau pameran budaya (pada jadwal tertentu).

Variabel promosi merupakan teknik komunikasi yang secara penggunaannya atau penyampaiannya dengan menggunakan media seperti: pers, televisi, radio, papan nama, poster

Vol.14 No.2 September 2019 
dan lain-lain, yang tujuannya untuk menarik konsumen terhadap keputusan pembelian, signifikan dan dapat menjadi perhatian UMKM melalui pelaku usaha untuk dapat meningkatkan pendapatan dan perluasan pasar dengan promosi sebagai media untuk menjembatani kepentingan UMKM dengan konsumen.

Tujuan daripada promosi dalam penelitian ini melalui perumusan masalahnya agar konsumen membeli hasil produksinya, secara positif dapat meningkatkan volume penjualan dan juga dapat memperluas pasar. Hal ini dapat dicapai oleh suatu UMKM bila promosi yang dijalankan benar-benar tepat sehingga pelaksanaan promosi dapat berhasil seefektif mungkin.

Hasil penelitian menunjukkan bahwa peran promosi berpengaruh positif dan signifikan terhadap keputusan pembelian, artinya jika promosi semakin tinggi akan mempengaruhi tingginya keputusan pembelian. Promosi dapat memberikan ruang pemasaran dalam produk dengan komunikasi pemasaran dalam strategi desain untuk memberikan informasi mengenai produk yang berkualitas. Informasi dengan promosi mengenai kualitas produk tas dan sepatu berbahan rotan di Palangka Raya, yang didapat dari iklan atau orang lain dapat membentuk suatu sikap dan perilaku konsumen untuk melakukan pembelian. Jika persepsi mereka akan produk berkualitas semakin kuat akan menguatkan sikap dan pada akhirnya akan mempengaruhi niat untuk membeli produk (keputusan pembelian/pembelian ber-ulang).

\section{PENUTUP}

\section{Kesimpulan}

Promosi dalam penelitian ini menunjukkan hasil yang positif dan signifikan terhadap keputusan pembelian, artinya jika promosi UMKM tas dan sepatu berbahan dasar Rotan semakin tinggi maka berpengaruh keputusan pembelian. Peran promosi menyatakan bahwa tujuan utama promosi adalah menginformasikan, mempengaruhi dan membujuk serta mengingatkan pelanggan sasaran tentang pemasaran dan bauran pemasaran, dapat meningkatkan pendapatan dan memperluas pasar. sehingga, UMKM di harapkan dapat meningkatkan strategi pemasaran dengan dynamic capability dalam menjawab permasalahan dalam meningkatkan pendapatan serta perluasan pasar di lingkungan bisnis yang kompetitif, baik dengan promosi iklan percetakan, elektronik atau digitalisasi.

Beberapa saran adalah untuk meningkatkan keputusan pembelian, disarankan kegiatan promosi yang berupa pemberian diskon, pemberian hadiah langsung dan garansi harus tetap dilakukan terus agar minat konsumen semakin tinggi dan tertarik untuk membeli. Kepaada pihak eksternal untuk dapat melibatkan UMKM dalam kegiatan yang dapat memberikan nilai "promosi" seperti kontes/event yang dilakukan secara berkala untuk dapat lebih lagi membangun hubungan yang baik dengan pelanggan, dan perluasan pasar. Penelitian selanjutnya dapat memasukkan variabel lain yang relevan untuk mengukur tingkat keputusan pembelian dan dapat di lakukan dengan uji kuantitatif atau mix methods.

\section{DAFTAR PUSTAKA}

[1] Abdul-Mohsin, A. M., Abdul-Halim, H., \& Ahmad, N. H. (2012). Delving into the Issues of Entrepreneurial Attitude Orientation and Market Orientation among the SMEs-A Conceptual Paper. Procedia - Social and Behavioral Sciences, 65, 731-736. doi: 10.1016/j.sbspro.2012.11.191

[2] Adeniran, T. V., \& Johnston, K. A. (2012). Investigating the dynamic capabilities and competitive advantage of South African SMEs. African Journal of Business Management, 6(11), 4088-4099. doi: http://dx.doi.org/10.5897/AJBM11.1673

[3] Ahmed, M. U., Kristal, M. M., \& Pagell, M. (2014). Impact of operational and marketing capabilities on firm performance: Evidence from economic growth and downturns. International Journal of Production Economics, 154, 59-71. doi: 10.1016/j.ijpe.2014.03.025

http://ejurnal.binawakya.or.id/index.php/MBI 
[4] Alan, T. B., William, A., \& Pratim, D. (2011). A qualitative exploration of entrepreneurial knowledge transfers. Journal of Knowledge Management, 15(2), 270-298. doi: 10.1108/13673271111119691

[5] Arch, G. W. (2003). Middle-range theory construction of the dynamics of organizational marketing-buying behavior. Journal of Business \& Industrial Marketing, 18(4/5), 309-335. doi: $10.1108 / 08858620310480232$

[6] Avlonitis, G. J., \& Panagopoulos, N. G. (2010). Selling and sales management: An introduction to the special section and recommendations on advancing the sales research agenda. Industrial Marketing Management, 39(7), 1045-1048. doi: 10.1016/j.indmarman.2009.12.006

[7] Bauer, M., \& Auer-Srnka, K. J. (2012). The life cycle concept in marketing research. Journal of Historical Research in Marketing, 4(1), 68-96. doi: http://dx.doi.org/10.1108/175575012111950 73

[8] Buil, I., de Chernatony, L., \& Martínez, E. (2013). Examining the role of advertising and sales promotions in brand equity creation. Journal of Business Research, 66(1), 115-122. doi: 10.1016/j.jbusres.2011.07.030

[9] Chan, C. C. H., Cheng, C.-B., \& Hsien, W.C. (2011). Pricing and promotion strategies of an online shop based on customer segmentation and multiple objective decision making. Expert Systems with Applications, 38(12), 14585-14591. doi: 10.1016/j.eswa.2011.05.024

[10]E. Schultz, D., \& P. Block, M. (2014). Sales promotion influencing consumer brand preferences/purchases. Journal of Consumer Marketing, 31(3), 212-217. doi: 10.1108/jcm-01-2014-0822

[11] Epstein, L. D., Flores, A. A., Goodstein, R. C., \& Milberg, S. J. (2016). A new approach to measuring retail promotion effectiveness: A case of store traffic. Journal of Business
Research, 69(10), 4394-4402. doi: 10.1016/j.jbusres.2016.03.062

[12]Hsu, Y. (2011). Design innovation and marketing strategy in successful product competition. The Journal of Business \& Industrial Marketing, 26(4), 223-236. doi: http://dx.doi.org/10.1108/088586211111269 74

[13] Kåre, S., \& Kjell, G. (2010). Chinese food retailers' positioning strategies and the influence on their buying behaviour. Asia Pacific Journal of Marketing and Logistics, 22(2), 196-209. doi: $10.1108 / 13555851011026944$

[14] Kotler, P., \& Armstrong, G. (2011). Principles of Marketing.

[15] Moharam, O. M., \& Shawky, A. Y. (2012). Measuring The Effects of Personalized Integrated Marketing Communication Tools on the Consumers" Intention to Purchase Credit Cards in the Private Banking Sector in Egypt. American Academic \& Scholarly Research Journal, 4(5), 1-14.

[16] Morris, M. H., Schindehutte, M., \& LaForge, R. W. (2002). Entrepreneurial marketing: A construct for integrating emerging entrepreneurship and marketing perspectives. Journal of Marketing Theory and Practice, 10(4), 1-19.

[17] Sulistyo, H., \& Siyamtinah. (2016). Innovation capability of SMEs through entrepreneurship, marketing capability, relational capital and empowerment. Asia Pacific Management Review, 21(4), 196203. doi: 10.1016/j.apmrv.2016.02.002

[18] Teece, D. J., Pisano, G., \& Shuen, A. (1997). Dynamic Capabilities and Strategic Management. Strategic Management Journal, 18(7), 509.

[19] Weitz, B. A., \& Bradford, K. D. (1999). Personal Selling and Sales Management: A Relationship Marketing Perspective. Journal of the Academy of Marketing Science, 27, 241-254.

[20]Zineldin, M., \& Philipson, S. (2007). Kotler And Borden Are Not Dead: Myth of Relationship Marketing And Truth of The Vol.14 No.2 September 2019 
4Ps. Journal of Consumer Marketing, 24(4), 229-241. doi: 10.1108/07363760710756011 